\title{
How Intangible Assets Affect the Corporate Financial Performances and How It Varies from Sector - to - Sector?
}

\author{
Geoffrey VanderPal \\ Purdue University Global
}

To explore the varied perspectives of intangible assets and corporate financial performance nexus, this study employs various measures, i.e. Generalized Method of Moments (GMM). Analysis reveals significant variances in different asset classes and in different sectors. The findings provide insights in

risk-return paradigm of intangible investments and the successive returns besides helping the policy makers to settle the priority sector to get the expected result in line with the country's investment policy.

Keywords: Intangible Assets, Corporate Finance, Financial Performance, investment policy, sector performance

\section{INTRODUCTION}

Within an industry, intangible asset(s) is the main factor of differentiation and competitiveness of enterprises (Penman, 2009). Hence, in order to gain competitive advantage, firms undertake costly activities to develop innovations (Thatcher \& Pingry, 2009). Recognizing the significance, in recent years, there has been an increasing interest among academics from different field of studies to understand the relationship dynamics between intangible assets and financial performance. At large, intangibles have positive effects on firm value and profitability, and an indicator for future financial performance (Chen, Cheng, \& Hwang, 2005). However, previously published studies on the effect of intangible assets are not consistent. What is less clear is the nature of relationships for diverse sectors - whether and how such relationship dynamics varies. This paper attempts to show sectoral differences of the intangible assets financial performance nexus. Besides, the Generalized Method of Moments (GMM) are employed to catch on the lag effect bearing in mind that the intangible expense outcome is not immediate.

This study aims to contribute to this growing area of research by exploring the relationship from diverse viewpoints. The study aims to examine the role of corporate intangible assets on their financial performance. Besides looking into the intangible expense, it considers the ratio of intangible assets to firm's total assets, to recognize how much the possession of intangibles are beneficial from the perspective of firm's asset holding.

The next section presents the literature review on intangibles and present the gap in the existing literature. This is followed by a section that describes the data, methodology and the econometric aspects of the study and present the empirical models to achieve the study objective. Then, the main findings and discussion are presented. The paper concludes with a discussion on the implications of the findings. 


\section{LITERATURE REVIEW}

The current study reflects a knowledge-based perspective of firms which consider organizations as repositories of knowledge (Grant, 1996; Kogut \& Zander, 1992). This view highlights the role of intangible resources, in combination with physical assets, in developing the required competitive advantage (Denicolai, Zucchella, \& Strange, 2014). Such an advantage is viable if firms can transmit their investments in creating intangible assets that would enhance their financial performance. There are numerous theoretical perspectives that describe the relationship, which include the dynamic resourcebased view (Helfat and Peteraf, 2003), and this has been confirmed by a number of empirical studies (e.g. Eberhart, Maxwell \& Siddique, 2004; Lome, Heggeseth \& Moen, 2016).

The study of competitive advantage driven by Intellectual property (IP) requires the identification of certain critical factors, such as those referred to by the literature here. These elements allow businesses to enjoy competitive advantages in terms of market power. The expenditures signal the strategic positioning of a firm and significantly put a strain on the firm's financial performances (Lantza \& Sahutb, 2005; Rivette \& Klein, 2008). Investors also accept investments in intangibles without any reserves (GarciaGarcia \& Magdaleno, 2010). Firms can therefore enjoy extra benefits by such investments in creating intangibles.

Since businesses are becoming more complex, dynamic and globally competitive, knowledgeable and intelligent workers have become valuable intangible assets who contribute towards creating value. Hence, it has been extensively established that at present, the most essential value generating resources are intangible in nature, and to be precise, are related to the skills and knowledge embedded in an organisation (Kiant, Andreeva, \& Pavlov, 2013). Innovation is usually positively correlated with return on assets (Sher and Yang, 2005; Gamayuni, 2015). Yet, the propensity to invest in intangible assets are not homogeneous and surges according to the firm's size, human capital, and historical intangible asset base (Arrighetti, Landini, \& Lasagni, 2014). Moreover, the value of intangible assets is more volatile than the value of tangible assets, and any changes increase the difference between the book value and market value (Garger, 2010).

Nonetheless, for US firms, the value of total assets increased by $57 \%$ when intangible capital are measured in addition to conventional financial accounts (Hulten \& Hao, 2008). There is a positive influence by internal intangible capital on firms' productivity levels (Marrocu, Paci, \& Pontis, 2012). The ownership of intangible assets also translates into superior organisational performance (Menor, Kristal, \& Rosenzweig, 2007; Hsu \& Sabherwal, 2011). Moreover, firms with feasible intangible assets are able to not only perform and grow locally but also internationally. Considering the firms' knowledge-based views, more knowledge assets have a positive impact on foreign sales intensity; which in turn influences firms' financial performances altogether (Denicolai et al., 2014). Analyses largely indicate that investment in intangibles enhances the value of a company (VanderPal, 2015). However, Denicolai et al., (2014) argue that such progressive impact of intangible assets can be enjoyed only up to a certain point. Their analysis of inverse quadratic relationship suggested the need to balance knowledge assets with complementary assets in order to achieve a higher degree of international performance.

Past studies have discussed the impacts of possessing intangible assets and consequential performance of firms, particularly their financial performance. The effect of such expenditure was found heterogeneous for growing or shrinking firms (Coad \& Rao, 2009). The inconclusiveness in the current literature points to the need for further investigation to ascertain the impact of intangibles assets on financial performance.

\section{METHODOLOGY AND ANALYSIS}

Different methodologies employed to accomplish the study objectives where the key interest is to find out the how firms' financial performances are affected by investing intangibles. Sectoral segregation is made to comprehend the sector-wise idiosyncrasy. For this study, we collected the data from Compustat's S\&P 500 companies. Data frequency is annual and it covers a range from 1979-2015. 
In statistics, ordinary least squares (OLS) is a method for estimating the unknown parameters in a linear regression model. The OLS is considered a classical estimation method as the OLS estimator provides minimum-variance mean-unbiased estimation when the errors are homoscedastic and serially uncorrelated. However, one important issue is that most models have to concern is the endogeneity problem which occurs when an explanatory variable correlates with the error term due to omitted variables, measurement errors, or simultaneity (Wooldridge, 2006). For the current study, companies' ownership of intangible assets are endogenous and is correlated with the error term and the classical OLS regression model might produce inefficient regression coefficient. To overcome these possible problems, the study uses the generalized method of moments (GMM) estimators developed for dynamic panel data that was first introduced by Hansen (1982) and proposed by Holtz-Eakin et al. (1988) and Arellano \& Bond (1991). The GMM estimator has several advantages in particular for this study. Firstly, the GMM is an appropriate method for the research data structure and it performs well for the unbalanced dataset. Secondly, it can reduce the endogeneity problem due to the potential correlation between regressors and the error term. Thirdly, this research use lagged dependent variables, thus, the dynamic GMM panel is the most appropriate method to address this type of data structure. Fourth, dynamic GMM panel data estimation is more appropriate in cases where some unobservable factors affect both the dependent variable and the explanatory variables and some explanatory variables are strongly related to past values of the dependent variable. Furthermore, introducing lagged values of the dependant variable in OLS estimators may seriously bias estimated coefficients (Nickell, 1981). In consideration of the above, heteroskedasticity and the properties of our panel dataset, Arellano and Bond's two-step difference GMM estimator is used. This dynamic Generalised Methods of Moments (GMM) estimator ensures a consistent and reliable estimation of the parameters of interest (Roodman, 2006). In general, the consistency of GMM estimator depends on the validity of the assumption that the error terms do not exhibit serial correlation and on the validity (exogeneity) of its instruments. To validate these assumptions, STATA $^{1}$ offers two sets of specification tests. The first set constitutes Sargan ${ }^{2}$ and Hansen test $^{3}$ of over-identification.

To check for first-order serial correlation in levels, we look for second-order correlation in differences AR (2) (Mileva, Bruhn, \& Weickert, 2007). Autocorrelation in levels indicates that lags of the dependent variable (and any other variables used as instruments) are not strictly exogenous but in fact endogenous, thus bad instruments. Failure to reject the null hypotheses of the over-identification and serial correlation tests gives support to our model.

To eliminate the potential bias caused by omitted heterogeneity, we can either use fixed effects or random effects models. If the independent variables are uncorrelated with the unobserved effect ( $\mu \mathrm{i})$, the fixed effects estimator is consistent but inefficient, whereas the random effects estimator is consistent and efficient. If the independent variables are correlated with the unobserved heterogeneity $(\mu \mathrm{i})$, the fixed effects estimator is consistent, while the random effects estimator is inconsistent (Baum, 2006). So, to identify the appropriate estimation model, we run the Hausman test. If the null hypothesis is rejected, then we conclude that $\mu \mathrm{i}$ is correlated with the independent variables, i.e. the fixed effects is the appropriate method (Pasiouras \& Kosmidou, 2007; Petria, Capraru, \& Ihnatov, 2015). Moreover, assuming homoscedasticity of error terms in the presence of heteroscedasticity, as well as having autocorrelated disturbances, produces consistent but inefficient estimates, and the standard errors of these estimates will be biased (Baltagi, 2005). Therefore, we shall estimate robust standard errors to correct for the possible presence of these issues.

At this level, we empirically test the effect of intangible assets on firm's financial performance using this model.

$\mathrm{FINi}, \mathrm{t}=\alpha \mathrm{i}+\tau \mathrm{t}+\beta 1 \mathrm{INTit}+\beta 2 \mathrm{Cit}+\varepsilon \mathrm{it}$

where: FINit represents financial performance; $\alpha \mathrm{i}$ is a dummy variable to control for time-invariant firmspecific factors (e.g., assets, sales etc.); $\tau \mathrm{t}$ is a year dummy variable to control for time-varying common shocks; INTit is for intangible assets, Cit is a vector of firm-specific variables; Eit is the normally distributed error term; $i$ and $t$ are indexes for cross-section and time-series, respectively, with $i=1, \ldots ., N$, 
$t=1, \ldots, T$. Positive sign of $\beta 1$ and significant $p$ value indicates the existence of mission drift. Equation (1) specifies the overall model for the study. The equation is used to define different sectoral models by including all the variables and then modifying it for different sectors' data.

TABLE 1

LIST OF VARIABLES

\begin{tabular}{|c|c|}
\hline Variable Name & Symbol \\
\hline Assets-Total & AST \\
\hline EBIT & EBI \\
\hline Intangibles-Other & INT \\
\hline Net Income (Loss) & NEI \\
\hline Operating Income Before Depreciation & OPI \\
\hline Price-Close Calendar Year & PRI \\
\hline $\mathrm{ROA}$ & ROA \\
\hline ROE & ROE \\
\hline Sales-Net & SAL \\
\hline Intangible Assets Ratio & $\mathrm{INT} / \mathrm{AST}$ \\
\hline
\end{tabular}

Following the methodology explained, we report and analyse the various estimations (i.e. GMM and static panel threshold). In general, the results of most estimations indicate the significance of the lag dependent variable (i.e.), in line with earlier findings in other empirical studies (Name some references) that what confirm the appropriateness of using the GMM and Panel threshold technique.

\section{Descriptive Statistics}

Table 2 summarizes the median values of our main variables of corporate firms. It presents the summary statistics for the aggregated data. Clearly, the data are characterised by their heterogeneity, where the differences among corporate firms are significant.

TABLE 2

DESCRIPTIVE STATISTICS

\begin{tabular}{lccccc}
\hline Variable & No. of Observations & Mean & Standard Deviation & Minimum & Maximum \\
\hline ROA & 14314 & 5.259422 & 11.52165 & -577.85 & 90.66 \\
ROE & 14008 & 15.35914 & 159.9642 & -14132 & 7038.46 \\
INT & 6484 & 1966.882 & 7134.023 & 0 & 169054 \\
INTAST & 14322 & 0.028055 & 0.0720645 & 0 & 0.810795 \\
LAST & 14322 & 8.569283 & 1.930882 & -1.17766 & 14.76063 \\
LNEI & 13037 & 5.611215 & 1.773562 & -6.90776 & 11.56001 \\
LEBI & 13714 & 6.209501 & 1.721655 & -3.07911 & 11.17367 \\
NEI & 14314 & 836.5912 & 2946.255 & -99289 & 104821 \\
OPI & 13723 & 2238.955 & 5350.579 & -76735 & 81730 \\
PRI & 13913 & 32.88359 & 59.03339 & 0.01 & 1971.25 \\
\hline
\end{tabular}

Correlation Coefficient

Table 3 provides the matrix of Pearson correlation coefficients that based on the results, indicates relatively weak association between the variables. 
TABLE 3

CORRELATION COEFFICIENT

\begin{tabular}{lrrrrrrrrrr}
\hline Variable & \multicolumn{1}{l}{ ROA } & \multicolumn{1}{l}{ ROE } & INT & INTAST & LAST & LNEI & LEBI & NEI & OPI & PRI \\
\hline ROA & 1 & & & & & & & & & \\
ROE & 0.1457 & 1 & & & & & & & & \\
INT & -0.1131 & -0.0134 & 1 & & & & & & & \\
INTAST & -0.1261 & -0.0032 & 0.4984 & 1 & & & & & & \\
LAST & -0.1836 & -0.0041 & 0.446 & 0.1504 & 1 & & & & & \\
LNEI & 0.2576 & 0.0504 & 0.3695 & 0.0874 & 0.8619 & 1 & & & & \\
LEBI & 0.1405 & 0.0516 & 0.3917 & 0.1272 & 0.9109 & 0.9449 & 1 & & & \\
NEI & 0.1852 & 0.0309 & 0.4036 & 0.062 & 0.6526 & 0.7036 & 0.6845 & 1 & & \\
OPI & 0.052 & 0.0173 & 0.5119 & 0.0731 & 0.7103 & 0.681 & 0.7075 & 0.9282 & & 1 \\
PRI & 0.1306 & 0.0221 & 0.0422 & 0.0651 & 0.1722 & 0.2282 & 0.222 & 0.1507 & 0.1146 & 1 \\
\hline
\end{tabular}

TABLE 4

BASELINE MODEL: FINANCIAL PERFORMANCE AND INTANGIBLE ASSETS

\begin{tabular}{|c|c|c|c|c|}
\hline & $\mathrm{ROA}$ & $\mathrm{ROE}$ & ROA & $\mathrm{ROE}$ \\
\hline & INT & INT & INT/AST & INT/AST \\
\hline L.ROA & $\begin{array}{c}-0.0382^{* * *} \\
(-8.13)\end{array}$ & & $\begin{array}{c}0.00416 \\
(1.15)\end{array}$ & \\
\hline L.ROE & & $\begin{array}{c}0.0357^{* *} \\
(2.97)\end{array}$ & & $\begin{array}{c}-0.0286^{* * *} \\
(-4.06)\end{array}$ \\
\hline INT & $\begin{array}{c}0.00000637 \\
(0.38)\end{array}$ & $\begin{array}{c}- \\
0.000284 \\
(-0.75)\end{array}$ & & \\
\hline INTAST & & & $\begin{array}{c}-2.687^{* * *} \\
(-4.12)\end{array}$ & $\begin{array}{l}-46.60 \\
(-1.62)\end{array}$ \\
\hline LAST & $\begin{array}{l}-5.610^{* * *} \\
(-43.81)\end{array}$ & $\begin{array}{l}-9.908^{* *} \\
(-3.11)\end{array}$ & $\begin{array}{c}-5.414^{* * *} \\
(-78.21)\end{array}$ & $\begin{array}{c}-10.62^{* * *} \\
(-3.47)\end{array}$ \\
\hline LNEI & $\begin{array}{l}2.750^{* * * *} \\
(31.70)\end{array}$ & $\begin{array}{l}5.148^{*} \\
(2.57)\end{array}$ & $\begin{array}{l}2.327^{* * *} \\
(46.21)\end{array}$ & $\begin{array}{l}5.419^{*} \\
(2.45)\end{array}$ \\
\hline LEBI & $\begin{array}{l}2.034^{* * * *} \\
(15.15)\end{array}$ & $\begin{array}{l}4.803 \\
(1.55)\end{array}$ & $\begin{array}{c}2.413^{* * *} \\
(29.58)\end{array}$ & $\begin{array}{l}7.432^{*} \\
(2.10)\end{array}$ \\
\hline NEI & $\begin{array}{c}0.000895^{* * *} \\
(24.20)\end{array}$ & $\begin{array}{c}0.00143 \\
(1.49)\end{array}$ & $\begin{array}{c}0.000873^{* * *} \\
(29.52)\end{array}$ & $\begin{array}{c}0.00241 \\
(1.72)\end{array}$ \\
\hline OPI & $\begin{array}{c}-0.000430^{* * *} \\
(-15.56)\end{array}$ & $\begin{array}{c}0.000252 \\
(0.40)\end{array}$ & $\begin{array}{c}-0.000411^{* * *} \\
(-17.94)\end{array}$ & $\begin{array}{c}-0.00152 \\
(-1.53)\end{array}$ \\
\hline PRI & $\begin{array}{c}-0.000903 \\
(-0.78)\end{array}$ & $\begin{array}{c}0.0814^{* *} \\
(2.62)\end{array}$ & $\begin{array}{c}0.00110 \\
(1.24)\end{array}$ & $\begin{array}{c}-0.0364 \\
(-0.85)\end{array}$ \\
\hline SAL & $0.0000254^{* * *}$ & 0.000149 & $0.0000175^{* * *}$ & $0.000652^{* *}$ \\
\hline Constant & $\begin{array}{c}(3.72) \\
27.95^{* * *} \\
(31.38)\end{array}$ & $\begin{array}{c}(-0.98) \\
42.42 \\
(1.76)\end{array}$ & $\begin{array}{c}(3.33) \\
25.33^{* * *} \\
(69.92)\end{array}$ & $\begin{array}{l}(2.92) \\
29.57 \\
(1.80)\end{array}$ \\
\hline Observations & 5490 & 5345 & 11873 & 11660 \\
\hline
\end{tabular}


Given that the GMM standard errors are downward biased, robust standard errors are recommended. A robust version of the Sargan test however is available in STATA after specifying vce(robust). Given the limitations associated with the relatively short time span covered in our panel data set, we do not include any time trend component. Tests of joint significance are conducted but not reported. In line with the arbitrary rule of thumb suggested by Roodman (2009), the number of instruments doesn't the individual units (number of groups) in the panel suggesting potential problems of instrument proliferation are not apparent.

INT is found statistically insignificant with ROE for both proxies INT and INT/AST. With ROA, it is insignificant for INT but significant for INT/AST. Mostly, this result supports the proposition that intangible assets do not have significant effect on firm's financial performance. However, inconsistency of the results indicates the heterogeneity among the firms in term of asset class, nature of sectors. It also supports the possibility of multiple regimes in focus variables.

\section{Sectoral Analysis}

While aggregate analysis of financial performance offers an inclusive understanding of the effects intangible assets, a further sectoral analysis is able to give a more comprehensive understanding on the issue according to each industrial sector. There is a possibility of sector-specific growth, hence, there is a need to look at sector-specific sensitiveness (Sehrawat \& Giri, 2017). A large collection of heterogenous firms may also introduce statistical regularities that are only the result of the aggregation procedure (e.g., via Central Limit Theorem); however, such aggregate analyses may lead to ambiguous conclusions (Bottazzi, \& Secchi, 2003).

The sectoral differences in the coupling of revenues to outputs also imply greater pressure to improve performance in for-profit sectors (Kalleberg, Marsden, Reynolds, \& Knoke, 2006). It is important to note that the stride for profit and related activities fluctuate for sectors; for instance, financial, materials, and telecommunication service sectors are more volatile than healthcare, energy and consumer staples sectors (Bottazzi \& Secchi, 2003). Innovation activities in some service sectors such as telecommunications, transports and finance are associated with the establishment of expensive technological infrastructures, which require large financial resources and high demand. Consequently, for firms in these sectors, past economic performances might be more relevant as a basis for their overall financial commitment to innovation (Cainelli, Evangelista, \& Savona, 2005). Hence, there is the existence of widespread heterogeneity within each class and within each sector, as the production processes in quite diverse ways, and such heterogeneity does not occur with the same characteristics across industries (Bottazzi, Secchi, \& Tamagni, 2007. In reality, sectoral differences in dividend yields, capitalisations, and number of firms admitted to the sector accounted for more than two-third of the changes in market share. (Siegel \& Schwartz, 2006). Therefore, for the existence of sectoral specificities in business operation, the 'pooling' of firms operating in different industrial sectors may conceal the specific characteristics of the dynamics of firms operating in different sectors (Bottazzi \& Secchi, 2003). This calls for the need for data disaggregation to make more meaningful analysis.

The whole data samples are splitted into 10 sectors, followed by S\&P methodology. 
TABLE 5

SECTORAL CODE

\begin{tabular}{lc}
\hline Sector Name & Code \\
\hline Consumer Discretionary & 1 \\
Consumer Staples & 2 \\
Energy & 3 \\
Financials & 4 \\
Health Care & 5 \\
Industrials & 6 \\
Information Technology & 7 \\
Materials & 8 \\
Telecommunication Services & 9 \\
Utilities & 10 \\
\hline
\end{tabular}

TABLE 6

SECTOR: CONSUMER DISCRETIONARY

\begin{tabular}{lcccc}
\hline & ROA & ROE & ROA & ROE \\
\hline L.ROA & INT & INT & INT/AST & INT/AST \\
\hline L.ROE & 0.0201 & & 0.0350 & \\
& $(1.28)$ & & $(1.43)$ & \\
INT & & 0.0705 & & $0.122^{* *}$ \\
& & $(0.95)$ & & $(2.63)$ \\
INTAST & 0.0000202 & -0.00206 & & \\
& $(0.51)$ & $(-1.82)$ & & $-12.24^{*}$ \\
LAST & & & 0.271 & $(-2.09)$ \\
& & & $(0.52)$ & $-12.84^{* * *}$ \\
LNEI & $-4.029^{* * *}$ & $-42.45^{* *}$ & $-3.137^{* * *}$ & $(-6.44)$ \\
& $(-8.49)$ & $(-3.26)$ & $(-16.00)$ & $12.30^{* * *}$ \\
LEBI & 0.109 & $19.81^{* *}$ & $1.535^{* * *}$ & $(3.96)$ \\
& $(0.44)$ & $(2.58)$ & $(5.78)$ & 0.408 \\
NEI & $1.162^{* *}$ & $-27.16^{*}$ & $1.777^{* * *}$ & $(0.11)$ \\
& $(2.99)$ & $(-2.37)$ & $(5.61)$ & -0.0169 \\
OPI & $0.00728^{* * *}$ & -0.0197 & $0.00210^{*}$ & $(-1.65)$ \\
& $(9.83)$ & $(-0.87)$ & $(2.38)$ & $(1.14)$ \\
PRI & -0.00133 & 0.0304 & $-0.00183^{* *}$ & 0.00866 \\
& $(-1.76)$ & $(1.44)$ & $(-2.75)$ & 0.0333 \\
SAL & 0.000101 & 0.114 & 0.00257 & $(0.75)$ \\
& $(0.04)$ & $(1.59)$ & $(0.60)$ & $(0.30)$ \\
Constant & -0.0000517 & 0.00176 & 0.0000884 & 0.000225 \\
& $(-0.62)$ & $(0.77)$ & $(1.31)$ & $(8.59)$ \\
\hline Observations & $31.48^{* * * *}$ & $444.0^{* * *}$ & $12.18^{* * *}$ & $58.66^{* * *}$ \\
& $(7.56)$ & $(3.85)$ & $(17.92)$ & 66 \\
\end{tabular}


Given that the GMM standard errors are downward biased, robust standard errors are recommended. A robust version of the Sargan test however is available in STATA after specifying vce(robust). Given the limitations associated with the relatively short time span covered in our panel data set, we do not include any time trend component. Tests of joint significance are conducted but not reported. In line with the arbitrary rule of thumb suggested by Roodman (2009), the number of instruments doesn't the individual units (number of groups) in the panel suggesting potential problems of instrument proliferation are not apparent.

In table 6, For intangible assets, we find that it is statistically insignificant with ROA and ROE, but significant relationship is found between ROE and INTAST and it is negatively correlated.

TABLE 7

SECTOR: CONSUMER STAPLES

\begin{tabular}{lcccc}
\hline & ROA & ROE & ROA & ROE \\
\hline L.ROA & INT & INT & INT/AST & INT/AST \\
L.ROE & $0.134^{* * *}$ & & $0.125^{* * *}$ & \\
& $(5.22)$ & & $(6.18)$ & \\
INT & & $0.574^{* * *}$ & & -0.0285 \\
& -0.0000424 & $(10.31)$ & & $(-0.63)$ \\
& & 0.000946 & & \\
INTAST & $(-1.24)$ & $(-1.39)$ & & \\
& & & -1.215 & -714.5 \\
LAST & & & $(-1.04)$ & $(-1.28)$ \\
& $-5.983^{* * *}$ & $-13.72^{*}$ & $-4.432^{* * *}$ & -127.2 \\
LNEI & $(-16.02)$ & $(-2.07)$ & $(-21.26)$ & $(-1.39)$ \\
& $-0.555^{*}$ & -5.541 & $1.251^{* * *}$ & 12.97 \\
LEBI & $(-2.27)$ & $(-1.18)$ & $(9.47)$ & $(0.22)$ \\
& $6.521^{* * *}$ & 15.38 & $2.591^{* * *}$ & 35.49 \\
NEI & $(11.75)$ & $(1.48)$ & $(13.05)$ & $(0.40)$ \\
& $0.00129^{* * *}$ & 0.00737 & 0.000416 & -0.0199 \\
OPI & $(6.26)$ & $(1.84)$ & $(1.92)$ & $(-0.20)$ \\
& $-0.00118^{* * *}$ & -0.00359 & $-0.000352^{*}$ & -0.0425 \\
PRI & $(-6.17)$ & $(-0.92)$ & $(-2.16)$ & $(-0.55)$ \\
& $0.00596^{* *}$ & 0.0385 & $0.00750^{*}$ & 0.0310 \\
SAL & $(2.27)$ & $(0.88)$ & $(2.40)$ & $(0.02)$ \\
& $0.0000461^{* *}$ & 0.000318 & $0.0000349^{*}$ & $0.0189^{* *}$ \\
Constant & $(3.08)$ & $(1.19)$ & $(2.19)$ & $(2.67)$ \\
& $19.51^{* * *}$ & 59.40 & $20.10^{* * *}$ & 675.6 \\
Observations & $(10.36)$ & $(1.73)$ & $(14.76)$ & $(1.12)$ \\
\hline \multirow{4}{*}{137} & 135 & 297 & 295 \\
\hline & & & &
\end{tabular}

Given that the GMM standard errors are downward biased, robust standard errors are recommended. A robust version of the Sargan test however is available in STATA after specifying vee(robust). Given the limitations associated with the relatively short time span covered in our panel data set, we do not include any time trend component. Tests of joint significance are conducted but not reported. In line with the arbitrary rule of thumb suggested by Roodman (2009), the number of instruments doesn't the individual units (number of groups) in the panel suggesting potential problems of instrument proliferation are not apparent. 
In consumer staple sector table 7, both of the proxies of intangible assets are found statistically insignificant to financial performance. Results reveal that, intangible assets do not have any impact on firms' financial performance.

\section{TABLE 8}

\section{SECTOR: ENERGY}

\begin{tabular}{|c|c|c|c|c|}
\hline & ROA & ROE & ROA & ROE \\
\hline & INT & INT & INT/AST & INT/AST \\
\hline L.ROA & $\begin{array}{c}-0.0178 \\
(.)\end{array}$ & & $\begin{array}{c}-0.0332 \\
(-1.08)\end{array}$ & \\
\hline L.ROE & & $\begin{array}{c}0.0117 \\
(.)\end{array}$ & & $\begin{array}{c}0.0664 \\
(1.64)\end{array}$ \\
\hline INT & $\begin{array}{c}-0.00322 \\
(.)\end{array}$ & $\begin{array}{c}-0.00748 \\
(.)\end{array}$ & & \\
\hline INTAST & & & $\begin{array}{l}-9.512 \\
(-1.42)\end{array}$ & $\begin{array}{c}-50.05^{* *} \\
(-3.17)\end{array}$ \\
\hline LAST & & & $\begin{array}{l}-4.686^{* * *} \\
(-25.29)\end{array}$ & $\begin{array}{l}-6.203^{* * *} \\
(-14.84)\end{array}$ \\
\hline LNEI & & & $\begin{array}{c}2.115^{* * *} \\
(3.56)\end{array}$ & $\begin{array}{l}0.722 \\
(0.52)\end{array}$ \\
\hline LEBI & $\begin{array}{c}5.631 \\
(.)\end{array}$ & $\begin{array}{c}14.32 \\
(.)\end{array}$ & $\begin{array}{c}3.129^{* * *} \\
(4.81)\end{array}$ & $\begin{array}{c}5.333^{* * *} \\
(3.55)\end{array}$ \\
\hline NEI & $\begin{array}{c}0.00395 \\
(.)\end{array}$ & $\begin{array}{c}0.00533 \\
(.)\end{array}$ & $\begin{array}{c}0.00226^{* * *} \\
(3.57)\end{array}$ & $\begin{array}{c}0.00675^{* * *} \\
(4.56)\end{array}$ \\
\hline OPI & $\begin{array}{c}0.00993 \\
(.)\end{array}$ & $\begin{array}{c}0.0340 \\
\quad .()\end{array}$ & $\begin{array}{c}-0.00206^{* * *} \\
(-3.83)\end{array}$ & $\begin{array}{c}-0.00310^{*} \\
(-2.53)\end{array}$ \\
\hline PRI & $\begin{array}{c}-0.890 \\
(.)\end{array}$ & $\begin{array}{c}-2.693 \\
(.)\end{array}$ & $\begin{array}{c}0.00561 \\
(0.55)\end{array}$ & $\begin{array}{c}0.0404 \\
(1.68)\end{array}$ \\
\hline SAL & 0.0000120 & 0.0000523 & 0.00000879 & $\begin{array}{c}- \\
0.00000540\end{array}$ \\
\hline Constant & $\begin{array}{c}(.) \\
-37.40 \\
(.)\end{array}$ & $\begin{array}{c}(.) \\
-100.1 \\
(.)\end{array}$ & $\begin{array}{l}(1.44) \\
16.06^{* * *} \\
(11.45)\end{array}$ & $\begin{array}{c}(-0.38) \\
26.31^{* * *} \\
(7.98)\end{array}$ \\
\hline Observations & 8 & 8 & 36 & 36 \\
\hline
\end{tabular}

Given that the GMM standard errors are downward biased, robust standard errors are recommended. A robust version of the Sargan test however is available in STATA after specifying vce(robust). Given the limitations associated with the relatively short time span covered in our panel data set, we do not include any time trend component. Tests of joint significance are conducted but not reported. In line with the arbitrary rule of thumb suggested by Roodman (2009), the number of instruments doesn't the individual units (number of groups) in the panel suggesting potential problems of instrument proliferation are not apparent.

In energy sector table 8 , both of the proxies of intangible assets are found statistically insignificant to financial performance. Results reveal that, intangible assets do not have any impact on firms' financial performance. 


\section{TABLE 9}

SECTOR: FINANCIALS

\begin{tabular}{|c|c|c|c|c|}
\hline & ROA & $\mathrm{ROE}$ & ROA & ROE \\
\hline & INT & INT & INT/AST & INT/AST \\
\hline L.ROA & $0.0932^{*}$ & & $0.124^{* * *}$ & \\
\hline & $(2.20)$ & & $(3.59)$ & \\
\hline L.ROE & & $\begin{array}{l}0.997^{* * *} \\
(11.89)\end{array}$ & & $\begin{array}{l}1.061^{* * * *} \\
(18.60)\end{array}$ \\
\hline INT & $\begin{array}{c}-0.000779 \\
(-1.40)\end{array}$ & $\begin{array}{c}0.00666 \\
(0.90)\end{array}$ & & \\
\hline INTAST & $(-11.11)$ & $(-4.61)$ & $\begin{array}{c}6.510 \\
(0.62) \\
(-16.57)\end{array}$ & $\begin{array}{l}118.8 \\
(1.16) \\
(-2.80)\end{array}$ \\
\hline LNEI & $\begin{array}{l}0.378 \\
(0.73)\end{array}$ & $\begin{array}{l}-2.497 \\
(-0.43)\end{array}$ & $\begin{array}{l}0.388 \\
(1.37)\end{array}$ & $\begin{array}{l}-4.553^{*} \\
(-2.17)\end{array}$ \\
\hline LEBI & $\begin{array}{c}8.429^{* * *} \\
(8.13)\end{array}$ & $\begin{array}{l}22.18^{*} \\
(2.12)\end{array}$ & $\begin{array}{l}7.036^{* * *} \\
(12.67)\end{array}$ & $\begin{array}{l}11.95^{* *} \\
(2.64)\end{array}$ \\
\hline NEI & $\begin{array}{c}0.00242^{* * *} \\
(5.77)\end{array}$ & $\begin{array}{c}0.0130^{* *} \\
(2.92)\end{array}$ & $\begin{array}{c}0.00277^{* * *} \\
(9.28)\end{array}$ & $\begin{array}{c}0.0142^{* * *} \\
(6.33)\end{array}$ \\
\hline OPI & $\begin{array}{c}-0.00199^{* * *} \\
(-6.22)\end{array}$ & $\begin{array}{c}-0.00248 \\
(-0.75)\end{array}$ & $\begin{array}{c}-0.00184^{* * *} \\
(-7.83)\end{array}$ & $\begin{array}{c}-0.00156 \\
(-0.83)\end{array}$ \\
\hline PRI & $\begin{array}{l}0.0139 \\
(1.93)\end{array}$ & $\begin{array}{c}0.0883 \\
(1.16)\end{array}$ & $\begin{array}{c}0.0209^{* *} \\
(3.22)\end{array}$ & $\begin{array}{c}-0.0621 \\
(-1.13)\end{array}$ \\
\hline SAL & $\begin{array}{c}0.000113^{* *} \\
(3.27)\end{array}$ & $\begin{array}{c}0.00104^{* *} \\
(2.84)\end{array}$ & $\begin{array}{c}0.0000925^{* *} \\
(3.08)\end{array}$ & $\begin{array}{c}0.0000312 \\
(0.13)\end{array}$ \\
\hline Constant & $\begin{array}{c}23.66^{* * *} \\
(9.54)\end{array}$ & $\begin{array}{c}135.0^{* * * *} \\
(5.17)\end{array}$ & $\begin{array}{c}26.60^{* * *} \\
(19.54)\end{array}$ & $\begin{array}{c}28.54^{* *} \\
(2.94)\end{array}$ \\
\hline Observations & 55 & 55 & 100 & 100 \\
\hline
\end{tabular}

Given that the GMM standard errors are downward biased, robust standard errors are recommended. A robust version of the Sargan test however is available in STATA after specifying vee(robust). Given the limitations associated with the relatively short time span covered in our panel data set, we do not include any time trend component. Tests of joint significance are conducted but not reported. In line with the arbitrary rule of thumb suggested by Roodman (2009), the number of instruments doesn't the individual units (number of groups) in the panel suggesting potential problems of instrument proliferation are not apparent.

In financial sector, table 9, intangible assets is found insignificant in financial sector, that means, intangible assets do not have any effect on firms' financial performance financial sector. Although this result can be different with different terms. 
TABLE 10

SECTOR: HEALTH CARE

\begin{tabular}{|c|c|c|c|c|}
\hline & ROA & ROE & ROA & ROE \\
\hline & INT & INT & INT/AST & INT/AST \\
\hline L.ROA & $-0.0869^{*}$ & $-0.0869^{*}$ & $-0.0818^{* * *}$ & \\
\hline & $(-2.42)$ & $(-2.42)$ & $(-5.51)$ & \\
\hline $\begin{array}{l}\text { L.ROE } \\
\end{array}$ & & & & $\begin{array}{c}-0.0633^{* * *} \\
(-4.78)\end{array}$ \\
\hline INT & $\begin{array}{c}0.00143 \\
(1.29)\end{array}$ & $\begin{array}{c}0.00143 \\
(1.29)\end{array}$ & & \\
\hline INTAST & & & $\begin{array}{c}48.00^{* * *} \\
(4.49)\end{array}$ & $\begin{array}{c}191.2^{* *} \\
(2.87)\end{array}$ \\
\hline LAST & $\begin{array}{l}-1.614 \\
(-0.19)\end{array}$ & $\begin{array}{l}-1.614 \\
(-0.19)\end{array}$ & $\begin{array}{c}-3.728^{* * *} \\
(-9.40)\end{array}$ & $\begin{array}{c}-10.48^{* * *} \\
(-7.54)\end{array}$ \\
\hline LNEI & $\begin{array}{l}1.632 \\
(0.45)\end{array}$ & $\begin{array}{l}1.632 \\
(0.45)\end{array}$ & $\begin{array}{l}0.484 \\
(1.64)\end{array}$ & $\begin{array}{l}2.229^{*} \\
(2.16)\end{array}$ \\
\hline LEBI & $\begin{array}{l}-2.523 \\
(-0.41)\end{array}$ & $\begin{array}{l}-2.523 \\
(-0.41)\end{array}$ & $\begin{array}{c}2.694^{* * * *} \\
(5.51)\end{array}$ & $\begin{array}{c}6.370^{* * *} \\
(4.19)\end{array}$ \\
\hline NEI & $\begin{array}{c}0.00269^{* *} \\
(2.85)\end{array}$ & $\begin{array}{c}0.00269^{* *} \\
(2.85)\end{array}$ & $\begin{array}{c}0.00313^{* * *} \\
(23.77)\end{array}$ & $\begin{array}{c}0.00958^{* * *} \\
(6.81)\end{array}$ \\
\hline OPI & $\begin{array}{c}-0.00124 \\
(-0.94)\end{array}$ & $\begin{array}{c}-0.00124 \\
(-0.94)\end{array}$ & $\begin{array}{c}-0.00169^{* * *} \\
(-5.67)\end{array}$ & $\begin{array}{c}-0.00345^{* *} \\
(-2.63)\end{array}$ \\
\hline PRI & $\begin{array}{l}0.138^{*} \\
(2.12)\end{array}$ & $\begin{array}{l}0.138^{*} \\
(2.12)\end{array}$ & $\begin{array}{c}0.0565^{* * *} \\
(3.42)\end{array}$ & $\begin{array}{c}0.217^{* * *} \\
(3.45)\end{array}$ \\
\hline SAL & $\begin{array}{c}-0.000107 \\
(-0.37)\end{array}$ & $\begin{array}{c}-0.000107 \\
(-0.37)\end{array}$ & $\begin{array}{c}-0.0000490 \\
(-0.76)\end{array}$ & $\begin{array}{c}0.0000505 \\
\quad(0.17)\end{array}$ \\
\hline Constant & $\begin{array}{l}24.73 \\
(0.37)\end{array}$ & $\begin{array}{l}24.73 \\
(0.37)\end{array}$ & $\begin{array}{c}18.02^{* * *} \\
(8.78)\end{array}$ & $\begin{array}{c}50.88^{* * *} \\
(6.74)\end{array}$ \\
\hline Observations & 27 & 27 & 98 & 86 \\
\hline
\end{tabular}

Given that the GMM standard errors are downward biased, robust standard errors are recommended. A robust version of the Sargan test however is available in STATA after specifying vce(robust). Given the limitations associated with the relatively short time span covered in our panel data set, we do not include any time trend component. Tests of joint significance are conducted but not reported. In line with the arbitrary rule of thumb suggested by Roodman (2009), the number of instruments doesn't the individual units (number of groups) in the panel suggesting potential problems of instrument proliferation are not apparent.

In Health care sector, table 10, unlike other sectors, intangible assets is found highly significant and positively correlated with both proxies of financial performance ROA and ROE. This results reveal that, higher expenditures in intangible assets help firms to perform better financially in healthcare sector.

The analysis failed to apply GMM technique to compute the values for industrials sectors because of inadequate data. 


\section{TABLE 11}

\section{SECTOR: INFORMATION TECHNOLOGY}

\begin{tabular}{|c|c|c|c|c|}
\hline & ROA & ROE & ROA & ROE \\
\hline & INT & INT & INT/AST & INT/AST \\
\hline L.ROA & $\begin{array}{c}-0.152 \\
\text { (.) }\end{array}$ & & $\begin{array}{c}0.00125 \\
(0.02)\end{array}$ & \\
\hline L.ROE & & $\begin{array}{c}-0.0675 \\
(.)\end{array}$ & & $\begin{array}{c}-0.0554 \\
(-0.88)\end{array}$ \\
\hline INT & $\begin{array}{c}-0.000581 \\
(.)\end{array}$ & $\begin{array}{c}-0.000673 \\
(.)\end{array}$ & & \\
\hline INTAST & & & $\begin{array}{l}7.135 \\
(0.26)\end{array}$ & $\begin{array}{l}-97.53 \\
(-1.57)\end{array}$ \\
\hline LAST & $\begin{array}{c}-6.426 \\
(.)\end{array}$ & $\begin{array}{c}-12.21 \\
(.)\end{array}$ & $\begin{array}{l}-0.261 \\
(-0.16)\end{array}$ & $\begin{array}{l}2.015 \\
(0.57)\end{array}$ \\
\hline LNEI & $\begin{array}{c}0.754 \\
(.)\end{array}$ & $\begin{array}{c}2.164 \\
(.)\end{array}$ & $\begin{array}{l}0.636^{* *} \\
(2.59)\end{array}$ & $\begin{array}{l}1.594^{\text {** }} \\
(2.94)\end{array}$ \\
\hline LEBI & $\begin{array}{c}-1.664 \\
(.)\end{array}$ & $\begin{array}{c}-4.266 \\
(.)\end{array}$ & $\begin{array}{l}2.003^{*} \\
(2.09)\end{array}$ & $\begin{array}{l}7.030^{* *} \\
(3.27)\end{array}$ \\
\hline NEI & $\begin{array}{c}0.00306 \\
(.)\end{array}$ & $\begin{array}{c}0.00602 \\
\text { (.) }\end{array}$ & $\begin{array}{c}0.00386^{* * *} \\
(4.24)\end{array}$ & $\begin{array}{c}0.00968^{* * *} \\
(4.79)\end{array}$ \\
\hline OPI & $\begin{array}{c}0.00000795 \\
\text { (.) }\end{array}$ & $\begin{array}{c}0.00109 \\
\text { (.) }\end{array}$ & $\begin{array}{c}-0.00128 \\
(-1.48)\end{array}$ & $\begin{array}{c}-0.00490^{*} \\
(-2.51)\end{array}$ \\
\hline PRI & $\begin{array}{c}-0.0210 \\
(.)\end{array}$ & $\begin{array}{c}-0.0415 \\
(.)\end{array}$ & $\begin{array}{c}-0.0284 \\
(-1.19)\end{array}$ & $\begin{array}{c}-0.0297 \\
(-0.55)\end{array}$ \\
\hline SAL & 0.0000644 & $\begin{array}{c}- \\
0.0000404\end{array}$ & -0.000212 & -0.000512 \\
\hline Constant & $\begin{array}{c}(.) \\
74.36 \\
(.)\end{array}$ & $\begin{array}{c}(.) \\
146.4 \\
(.)\end{array}$ & $\begin{array}{l}(-1.23) \\
-7.592 \\
(-0.57)\end{array}$ & $\begin{array}{l}(-1.35) \\
-54.93 \\
(-1.90)\end{array}$ \\
\hline Observations & 11 & 11 & 29 & 29 \\
\hline
\end{tabular}

Given that the GMM standard errors are downward biased, robust standard errors are recommended. A robust version of the Sargan test however is available in STATA after specifying vce(robust). Given the limitations associated with the relatively short time span covered in our panel data set, we do not include any time trend component. Tests of joint significance are conducted but not reported. In line with the arbitrary rule of thumb suggested by Roodman (2009), the number of instruments doesn't the individual units (number of groups) in the panel suggesting potential problems of instrument proliferation are not apparent.

Intangible assets are not found to have any impact on financial performance of the firms. 
TABLE 12

SECTOR: MATERIALS

\begin{tabular}{|c|c|c|c|c|}
\hline & $\mathrm{ROA}$ & ROE & ROA & ROE \\
\hline & INT & INT & INT/AST & INT/AST \\
\hline L.ROA & $\begin{array}{c}0.0583 \\
(1.53)\end{array}$ & & $\begin{array}{c}0.0134 \\
(0.87)\end{array}$ & \\
\hline L.ROE & & $\begin{array}{c}7.983^{* * *} \\
(9.65)\end{array}$ & & $\begin{array}{c}0.865^{* * *} \\
(4.02)\end{array}$ \\
\hline INT & $\begin{array}{c}-0.00182 \\
(-1.76)\end{array}$ & $\begin{array}{c}0.0404 \\
(0.73)\end{array}$ & & \\
\hline INTAST & $(-11.92)$ & (1.55) & $\begin{array}{c}-2.376 \\
(-0.51) \\
(-24.91)\end{array}$ & $\begin{array}{c}971.8^{* * *} \\
(6.76) \\
(-0.21)\end{array}$ \\
\hline LNEI & $\begin{array}{l}1.628 \\
(1.57)\end{array}$ & $\begin{array}{c}346.3^{* * *} \\
(5.55)\end{array}$ & $\begin{array}{l}0.532 \\
(1.40)\end{array}$ & $\begin{array}{l}-1.766 \\
(-0.14)\end{array}$ \\
\hline LEBI & $\begin{array}{c}4.216^{* * *} \\
(3.55)\end{array}$ & $\begin{array}{c}-437.5^{* * *} \\
(-5.75)\end{array}$ & $\begin{array}{l}7.592^{* * *} \\
(14.40)\end{array}$ & $\begin{array}{c}-0.0188 \\
(-0.00)\end{array}$ \\
\hline NEI & $\begin{array}{c}0.00885^{* * *} \\
(4.89)\end{array}$ & $\begin{array}{c}-0.791^{* * *} \\
(-7.31)\end{array}$ & $\begin{array}{c}0.0195^{* * *} \\
(29.81)\end{array}$ & $\begin{array}{c}0.0282 \\
(1.30)\end{array}$ \\
\hline OPI & $\begin{array}{c}-0.00245^{*} \\
(-2.41)\end{array}$ & $\begin{array}{c}0.505^{* * *} \\
(8.00)\end{array}$ & $\begin{array}{c}-0.00888^{* * *} \\
(-15.02)\end{array}$ & $\begin{array}{l}0.0355 \\
(1.81)\end{array}$ \\
\hline PRI & $\begin{array}{c}0.00571 \\
(0.56)\end{array}$ & $\begin{array}{l}1.577^{*} \\
(1.98)\end{array}$ & $\begin{array}{c}-0.0252^{*} \\
(-2.33)\end{array}$ & $\begin{array}{l}0.869^{*} \\
(2.24)\end{array}$ \\
\hline SAL & $\begin{array}{c}-0.000201^{* *} \\
(-2.89)\end{array}$ & $\begin{array}{c}-0.0186^{* * *} \\
(-3.97)\end{array}$ & $\begin{array}{c}-0.0000295 \\
(-0.46)\end{array}$ & $\begin{array}{c}-0.00865^{* * *} \\
(-4.09)\end{array}$ \\
\hline Constant & $\begin{array}{l}20.05^{* * *} \\
(10.40)\end{array}$ & $\begin{array}{c}171.3 \\
(1.31)\end{array}$ & $\begin{array}{l}19.56^{* * *} \\
(21.42)\end{array}$ & $\begin{array}{l}29.07 \\
(0.99)\end{array}$ \\
\hline Observations & 67 & 64 & 178 & 175 \\
\hline
\end{tabular}

Given that the GMM standard errors are downward biased, robust standard errors are recommended. A robust version of the Sargan test however is available in STATA after specifying vce(robust). Given the limitations associated with the relatively short time span covered in our panel data set, we do not include any time trend component. Tests of joint significance are conducted but not reported. In line with the arbitrary rule of thumb suggested by Roodman (2009), the number of instruments doesn't the individual units (number of groups) in the panel suggesting potential problems of instrument proliferation are not apparent.

In material sector, table 12, intangible assets ratio is found significant and positively correlated with ROE, but insignificant for ROA. 
TABLE 13

SECTOR: TELECOMMUNICATION SERVICES

\begin{tabular}{lcccc}
\hline & ROA & ROE & ROA & ROE \\
\hline L.ROA & INT & INT & INT/AST & INT/AST \\
L.ROE & 0.0176 & & 0.0704 & \\
& $(0.33)$ & & $(1.93)$ & \\
& & & & $0.186^{* * *}$ \\
INT & & $(1.81)$ & & $(3.92)$ \\
& & & & \\
INTAST & $.00131^{* * *}$ & -0.00272 & & \\
& $(3.45)$ & $(-1.54)$ & & -6.295 \\
LNEI & & & 0.0955 & $(-0.63)$ \\
& & & $(0.05)$ & $(-2.97)$ \\
LEBI & $(-11.44)$ & $(-3.34)$ & $(-15.60)$ & $3.606^{*}$ \\
& -1.171 & -2.696 & -0.488 & $(2.28)$ \\
NEI & $(-1.36)$ & $(-0.68)$ & $(-1.59)$ & $8.472^{*}$ \\
& $12.80^{* * *}$ & $20.49^{* *}$ & $11.15^{* * *}$ & $(2.26)$ \\
OPI & $(8.49)$ & $(3.01)$ & $(14.25)$ & 0.0128 \\
& $0.0164^{* * *}$ & 0.0218 & $0.0173^{* * *}$ & $(1.00)$ \\
PRI & $(4.82)$ & $(1.37)$ & $(7.26)$ & -0.0109 \\
& -0.00165 & -0.0250 & $-0.00489^{*}$ & $(-0.93)$ \\
SAL & $(-0.52)$ & $(-1.80)$ & $(-2.21)$ & -0.0287 \\
& $0.0201^{*}$ & -0.0569 & $0.0215^{* *}$ & $(-0.77)$ \\
Constant & $(2.34)$ & $(-1.50)$ & $(3.05)$ & $(0.19)$ \\
& $-0.00209^{* * *}$ & 0.00297 & $-0.00108^{* * *}$ & 0.000263 \\
\hline Observations & $(-4.97)$ & $(1.74)$ & $(-3.88)$ & $23.97^{*}$ \\
& $25.41^{* * *}$ & 14.54 & $23.12^{* * *}$ & $(2.08)$ \\
\hline
\end{tabular}

Given that the GMM standard errors are downward biased, robust standard errors are recommended. A robust version of the Sargan test however is available in STATA after specifying vce(robust). Given the limitations associated with the relatively short time span covered in our panel data set, we do not include any time trend component. Tests of joint significance are conducted but not reported. In line with the arbitrary rule of thumb suggested by Roodman (2009), the number of instruments doesn't the individual units (number of groups) in the panel suggesting potential problems of instrument proliferation are not apparent.

Unlike many other sectors, for telecommunication services, intangible assets is found positively significant. Though other proxies show insignificant result. Results reveal that higher expenditures in intangible assets of the firms in telecommunication services will create better financial performance. 
TABLE 14

SECTOR: UTILITIES

\begin{tabular}{|c|c|c|c|c|}
\hline & ROA & $\mathrm{ROE}$ & ROA & ROE \\
\hline & INT & INT & INT/AST & INT/AST \\
\hline L.ROA & $\begin{array}{c}0.135^{\text {*** }} \\
(3.48)\end{array}$ & & $\begin{array}{c}0.205^{* * *} \\
(5.93)\end{array}$ & \\
\hline L.ROE & & $\begin{array}{c}0.172^{* * *} \\
(3.53)\end{array}$ & & $\begin{array}{c}0.144^{* * *} \\
(3.90)\end{array}$ \\
\hline INT & $\begin{array}{c}-0.00437^{*} \\
(-2.34)\end{array}$ & $\begin{array}{c}-0.00718^{*} \\
(-2.22)\end{array}$ & & \\
\hline INTAST & & & $\begin{array}{l}-3.732 \\
(-0.45)\end{array}$ & $\begin{array}{l}-24.94 \\
(-1.67)\end{array}$ \\
\hline LAST & $\begin{array}{c}-6.475^{* * *} \\
(-6.99)\end{array}$ & $\begin{array}{c}-12.09^{* * *} \\
(-6.59)\end{array}$ & $\begin{array}{l}-9.080^{* * *} \\
(-17.00)\end{array}$ & $\begin{array}{l}-14.15^{* * *} \\
(-14.73)\end{array}$ \\
\hline LNEI & $\begin{array}{l}2.385 \\
(1.77)\end{array}$ & $\begin{array}{l}4.545 \\
(1.82)\end{array}$ & $\begin{array}{c}5.278^{* * *} \\
(7.60)\end{array}$ & $\begin{array}{c}7.331^{* * *} \\
(5.89)\end{array}$ \\
\hline LEBI & $\begin{array}{l}2.696^{*} \\
(2.22)\end{array}$ & $\begin{array}{l}3.005 \\
(1.26)\end{array}$ & $\begin{array}{c}2.548^{* * *} \\
(3.19)\end{array}$ & $\begin{array}{c}7.438^{* * *} \\
(4.77)\end{array}$ \\
\hline NEI & $\begin{array}{c}0.0159^{* * *} \\
(3.93)\end{array}$ & $\begin{array}{c}0.0107 \\
(1.60)\end{array}$ & $\begin{array}{c}0.0170^{* * *} \\
(3.49)\end{array}$ & $\begin{array}{c}0.0198^{*} \\
(2.52)\end{array}$ \\
\hline OPI & $\begin{array}{c}-0.0102^{* * *} \\
(-3.48)\end{array}$ & $\begin{array}{c}-0.00893 \\
(-1.84)\end{array}$ & $\begin{array}{c}-0.0164^{* * *} \\
(-3.93)\end{array}$ & $\begin{array}{c}-0.0282^{* * *} \\
(-4.04)\end{array}$ \\
\hline PRI & $\begin{array}{c}0.0200 \\
(1.47)\end{array}$ & $\begin{array}{c}0.000600 \\
(0.03)\end{array}$ & $\begin{array}{c}0.0331 \\
(1.77)\end{array}$ & $\begin{array}{c}0.0517 \\
(1.58)\end{array}$ \\
\hline SAL & $\begin{array}{c}0.00110 \\
(1.58)\end{array}$ & $\begin{array}{c}0.00399^{* *} \\
(3.09)\end{array}$ & $\begin{array}{c}0.00239^{* *} \\
(2.69)\end{array}$ & $\begin{array}{c}0.00479^{* *} \\
(3.04)\end{array}$ \\
\hline Constant & $\begin{array}{c}29.80^{* * * *} \\
(6.15)\end{array}$ & $\begin{array}{c}61.61^{* * *} \\
(5.46)\end{array}$ & $\begin{array}{c}34.28^{* * *} \\
(16.72)\end{array}$ & $\begin{array}{c}41.86^{* * *} \\
(11.17)\end{array}$ \\
\hline Observations & 58 & 57 & 104 & 102 \\
\hline
\end{tabular}

Given that the GMM standard errors are downward biased, robust standard errors are recommended. A robust version of the Sargan test however is available in STATA after specifying vce(robust). Given the limitations associated with the relatively short time span covered in our panel data set, we do not include any time trend component. Tests of joint significance are conducted but not reported. In line with the arbitrary rule of thumb suggested by Roodman (2009), the number of instruments doesn't the individual units (number of groups) in the panel suggesting potential problems of instrument proliferation are not apparent.

Statistical result in utilities sectors is found to be quite different from other sectors. It's the only sector where intangible assets is found negatively correlated with financial performance for both Proxies ROA and ROE. It refers that higher expenditures in intangible assets will result in lower financial performance. One obvious reason behind such findings is that utilities does not require much intellectual assets rather it is essential for people. 
TABLE 15

SUMMARY OF THE RESULTS

\begin{tabular}{|l|l|l|l|l|}
\hline $\begin{array}{l}\text { Effect of } \\
\text { Intangible assets } \\
\text { on Financial } \\
\begin{array}{l}\text { Performance } \\
\text { (ROA, ROE) }\end{array}\end{array}$ & INT & ROA, & Not-significant & $\begin{array}{l}\text { Diverse results, } \\
\text { Intangible assets mostly } \\
\text { do not effect financial } \\
\text { performance, exception } \\
\text { noticed. }\end{array}$ \\
\cline { 3 - 4 } & INT/AST & ROE & Not-significant & Significant, Negative \\
\cline { 3 - 4 } & & ROE & Not-significant & \\
\hline
\end{tabular}

TABLE 16

SECTORAL DIFFERENCES AND INTANGIBLE ASSETS -FINANCIAL PERFORMANCE RELATIONSHIPS

\begin{tabular}{|c|c|c|c|c|}
\hline Sectors & & & Findings & \multirow{25}{*}{$\begin{array}{l}\text { Comments } \\
\text { not found to have any } \\
\text { significant effect on financial } \\
\text { performance. However, the } \\
\text { Intangible assets/ Total assets } \\
\text { is found to have significant } \\
\text { impact on financial } \\
\text { performance of companies } \\
\text { from different sectors. For } \\
\text { Financials and IT sectors, it is } \\
\text { insignificant, For healthcare, } \\
\text { materials and telcom sectors it } \\
\text { is positively significant and } \\
\text { consumer, energy and utilities } \\
\text { sectors it is negatively } \\
\text { significant }\end{array}$} \\
\hline \multirow{4}{*}{$\begin{array}{l}\text { Sector 1: Consumer } \\
\text { Discretionary }\end{array}$} & \multirow[b]{2}{*}{ INT } & ROA, & Not-significant & \\
\hline & & ROE & Not-significant & \\
\hline & \multirow[b]{2}{*}{ INT/AST } & ROA & Not-significant & \\
\hline & & $\mathrm{ROE}$ & $\begin{array}{l}\text { Significant, } \\
\text { negative }\end{array}$ & \\
\hline \multirow[t]{4}{*}{$\begin{array}{l}\text { Sector 2: Consumer } \\
\text { Staples }\end{array}$} & \multirow[t]{2}{*}{ INT } & ROA, & Not-significant & \\
\hline & & ROE & Not-significant & \\
\hline & & ROA & Not-significant & \\
\hline & INT/AST & ROE & Not-significant & \\
\hline Sector 3: Energy & & ROA, & Not-significant & \\
\hline & INT & ROE & Not-significant & \\
\hline & & ROA & Not-significant & \\
\hline & INT/AST & ROE & $\begin{array}{l}\text { Significant, } \\
\text { negative }\end{array}$ & \\
\hline Sector 4: Financials & INT & ROA, & Not-significant & \\
\hline & & ROE & Not-significant & \\
\hline & & ROA & Not-significant & \\
\hline & INT/AST & ROE & Not-significant & \\
\hline Sector 5: Health & & ROA, & Not-significant & \\
\hline Care & INT & ROE & Not-significant & \\
\hline & INT/AST & ROA & $\begin{array}{l}\text { Significant, } \\
\text { Positive }\end{array}$ & \\
\hline & & ROE & $\begin{array}{l}\text { Significant, } \\
\text { Positive }\end{array}$ & \\
\hline Sector 6: Industrials & & ROA, & Not-significant & \\
\hline Sector 7: & INT & ROE & Not-significant & \\
\hline Information & & ROA & Not-significant & \\
\hline Technology & INT/AST & ROE & Not-significant & \\
\hline
\end{tabular}




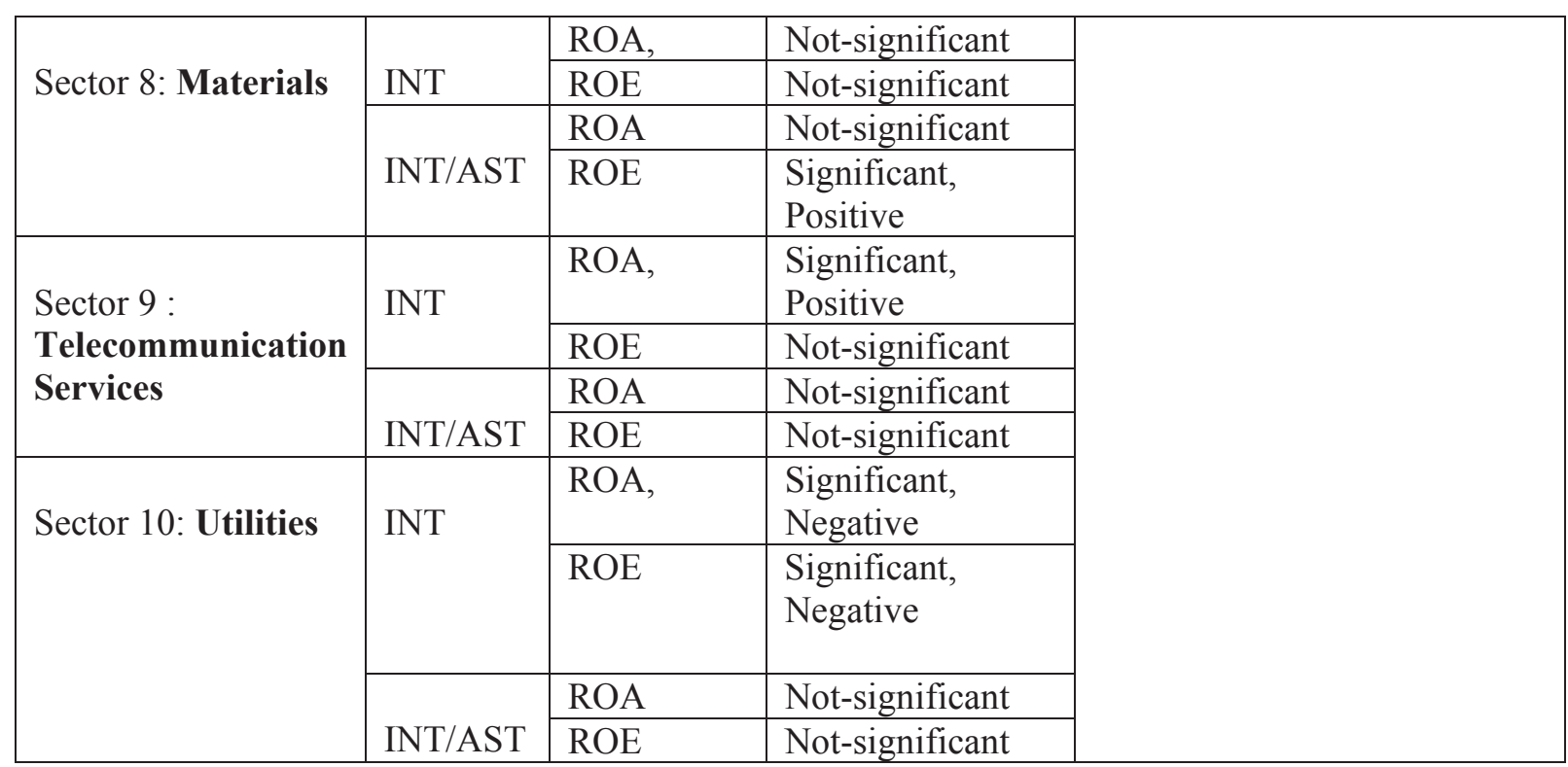

The current study intended to understand how such financial performance is influenced by firms' intangible assets. To do so, the study considers the ratio of intangible assets to firm's total assets and intangibles assets to measure the relationship. By employing the data from S\&P 500 companies over the period from 1979 to 2015 , the study finds diverse outcomes concerning the relationship. To attain comprehensive understanding the investigation further expands to sectoral analyses. Intangible assets itself is not found to have any significant effect on financial performance of the firms, although the Intangible assets/ Total assets ratio is found to have significant impact on financial performance of companies. For healthcare, materials and telecom sectors, the effect is positive and significant, while for consumer, energy and utilities sectors it is significant but negative; besides there was no significant statistical relationship was found for financials and IT sectors.

The research findings possess significant policy implications for different class of stakeholders as intangible assets are intense concerns for various parties. For the investors, the findings provide insights in risk-return paradigm in the framework of investment risk intangible assets holding by the firms and their subsequent return. Again, the sectoral performance differences indicate that investors needs to be sector sensitive while analysing firm's investment on intangible assets. The findings are also expected to help the financial managers to forecast the future return of a firm and also to measure the riskiness of financing and investment activities. In addition, this study contains noteworthy insights for the policy makers, government agencies and regulatory bodies; returns generated through intangible assets are vital to decide on the benefits, subsidization, taxation policy and such. Further, it is expected to aid the policy makers to settle on which sectors are worthy to be prioritized and how much be supported to get the expected result in line with country's investment policy. Also, notably the study adds value to the academia by considering intangibles' influence on corporate performance which is not clear in the existing literature. Besides answering some unsettled research problems and adding knowledge to the growing body of literature in this filed, the study unveils further avenue of research for academics.

The study endeavoured comprehensive analyses and a fairly novel attempt to understand the nexus; nevertheless, it is not devoid of some limitations mostly owing to unavailability of adequate data. The dataset comprises only S\&P 500 companies which are predominantly large companies based on developed economy (i.e. the USA), thus leads to lack of generalizability of the findings for the companies around the globe. Also, in some cases sufficient sectoral data were not available and levied restrictions on analyses. Likewise, the study did not take into consideration the institutional and governance variables. Since significant difference is found in asset-equity structure of the companies, further analyses with such variables could have been more insightful. Hence, future research may consider new dataset and 
incorporate regional analyses by giving consideration for institutional and political variables which will stretch better generalizability of the research. Furthermore, study can be further extended by considering threshold and asset size effect for different sectors as the current finding is somewhat heterogeneous.

\section{ENDNOTES}

1. A data analysis software

2. Over-identification test

3. Auto-correlation test

\section{REFERENCES}

Arrighetti, A., Landini, F., \& Lasagni, A. (2014). Intangible assets and firm heterogeneity: Evidence from Italy. Research Policy, 43(1), 202-213.

Bottazzi, G., \& Secchi, A. (2003). Common properties and sectoral specificities in the dynamics of US manufacturing companies. Review of Industrial Organization, 23(3-4), 217-232.

Bottazzi, G., Secchi, A., \& Tamagni, F. (2007). Productivity, Profitability and Financial Fragility: Empirical Evidence from Italian Business Firms.

Cainelli, G., Evangelista, R., \& Savona, M. (2005). Innovation and economic performance in services: a firm-level analysis. Cambridge Journal of Economics, 30(3), 435-458.

Cazavan-Jeny, A., Jeanjean, T., \& Joos, P. (2011). Accounting choice and future performance: The case of R\&D accounting in France. Journal of Accounting and Public Policy, 30(2), 145-165.

Cecchetti, S., \& Kharroubi, E. (2012). Reassessing the impact of finance on growth (No. 381). Bank for International Settlements.

Cha, H. S., Pingry, D. E., \& Thatcher, M. E. (2009). What determines IT spending priorities? Communications of the ACM, 52(8), 105-110.

Chen, M.-C., Cheng, S.-J., \& Hwang, Y. (2005). An empirical investigation of the relationship between intellectual capital and firms' market value and financial performance. Journal of Intellectual Capital, 6(2), 159-176.

Coad, A., \& Rao, R. (2010). Firm growth and R\&D expenditure. Economics of Innovation and New Technology, 19(2), 127-145.

Dave, P., Wadhwa, V., Aggarwal, S., \& Seetharaman, A. (2013). The impact of research and development on the financial sustainability of information technology (IT) companies listed on the S\&P 500 index. Journal of Sustainable Development, 6(11), 122.

Denicolai, S., Zucchella, A., \& Strange, R. (2014). Knowledge assets and firm international performance. International Business Review, 23(1), 55-62.

Eberhart, A. C., Maxwell, W. F., \& Siddique, A. R. (2004). An examination of long-term abnormal stock returns and operating performance following R\&D increases. The Journal of Finance, 59(2), 623650.

Gamayuni, R. R. (2015). The effect of intangible asset, financial performance and financial policies on the firm value. International Journal of Scientific \& Technology Research, 4(1), 202-212.

García-García, J., \& de Magdaleno, M. A. (2010). Fair value on Open Source business. XIV Encuentro AECA, Coimbra (Portugal).

Garger, J. (2010). Equity and market value: How much is a company worth to an investor.

Grant, R. M. (1996). Toward a knowledge-based theory of the firm. Strategic Management Journal, 17(S2), 109-122.

Hall, B. H., \& Lerner, J. (2010). The financing of R\&D and innovation. In Handbook of the Economics of Innovation (Vol. 1, pp. 609-639): Elsevier.

Helfat, C. E., \& Peteraf, M. A. (2003). The dynamic resource-based view: Capability lifecycles. Strategic Management Journal, 24(10), 997-1010. 
Hsieh, P-H., Mishra, C. S., \& Gobeli, D. H. (2003). The return on R\&D versus capital expenditures in pharmaceutical and chemical industries. IEEE Transactions on Engineering Management, 50(2), 141-150.

Hsu, I-C., \& Sabherwal, R. (2011). From intellectual capital to firm performance: the mediating role of knowledge management capabilities. IEEE Transactions on Engineering Management, 58(4), 626-642.

Hulten, C. R., \& Hao, X. (2008). What is a Company Really Worth? Intangible Capital and the" Market to Book Value" Puzzle.

Jirásek, M. (2017). The Relationship Between R\&D Spending Instability and a Firm 's Performance.

Jirásek, M. (2018). Financial Performance Feedback and R\&D: A Comparison of Different Models. Quality Innovation Prosperity, 22(1), 01-13.

Kalleberg, A. L., Marsden, P. V., Reynolds, J., \& Knoke, D. (2006). Beyond profit? Sectoral differences in high-performance work practices. Work and Occupations, 33(3), 271-302.

Kianto, A., Andreeva, T., \& Pavlov, Y. (2013). The impact of intellectual capital management on company competitiveness and financial performance. Knowledge Management Research \& Practice, 11(2), 112-122.

Kogut, B., \& Zander, U. (1992). Knowledge of the firm, combinative capabilities, and the replication of technology. Organization Science, 3(3), 383-397.

Kothari, S., Laguerre, T. E., \& Leone, A. J. (2002). Capitalization versus expensing: Evidence on the uncertainty of future earnings from capital expenditures versus R\&D outlays. Review of accounting Studies, 7(4), 355-382.

Lantz, J.-S., \& Sahut, J.-M. (2005). R\&D investment and the financial performance of technological firms. International Journal of Business, 10(3), 251.

Leitner, K. H. (2005). Managing and reporting intangible assets in research technology organisations. R\&D Management, 35(2), 125-136.

Lin, C.-H., Yang, H.-L., \& Liou, D.-Y. (2009). The impact of corporate social responsibility on financial performance: Evidence from business in Taiwan. Technology in Society, 31(1), 56-63.

Lome, O., Heggeseth, A. G., \& Moen, Ø. (2016). The effect of R\&D on performance: Do R\&D-intensive firms handle a financial crisis better? The Journal of High Technology Management Research, 27(1), 65-77.

Marrocu, E., Paci, R., \& Pontis, M. (2011). Intangible capital and firms' productivity. Industrial and Corporate Change, 21(2), 377-402.

Martin, M. (2015). Effectiveness of Business Innovation and R\&D in Emerging Economies: The Evidence from Panel Data Analysis. Journal of Economics Business and Management, 3(4), 440446.

Menor, L. J., Kristal, M. M., \& Rosenzweig, E. D. (2007). Examining the influence of operational intellectual capital on capabilities and performance. Manufacturing \& Service Operations Management, 9(4), 559-578.

Pandit, S., Wasley, C. E., \& Zach, T. (2011). The effect of research and development (R\&D) inputs and outputs on the relation between the uncertainty of future operating performance and R\&D expenditures. Journal of Accounting, Auditing \& Finance, 26(1), 121-144.

Penman, S.H. (2009), Accounting for intangible assets: there is also an income statement. Abacus, 45(3), 358-371.

Peterson, R. A., \& Jeong, J. (2010). Exploring the impact of advertising and R\&D expenditures on corporate brand value and firm-level financial performance. Journal of the Academy of Marketing Science, 38(6), 677-690.

Rafiq, S., Salim, R., \& Smyth, R. (2016). The moderating role of firm age in the relationship between R\&D expenditure and financial performance: Evidence from Chinese and US mining firms. Economic Modelling, 56, 122-132.

Roodman, D. (2009). A note on the theme of too many instruments. Oxford Bulletin of Economics and Statistics, 71(1), 135-158. 
Schimke, A., \& Brenner, T. (2014). The role of R\&D investments in highly R\&D-based firms. Studies in Economics and Finance, 31(1), 3-45.

Sehrawat, M., \& Giri, A. (2017). A Sectoral Analysis of the Role of Stock Market Development on Economic Growth: Empirical Evidence from Indian Economy. Global Business Review, 18(4), 911-923.

Sher, P. J., \& Yang, P. Y. (2005). The effects of innovative capabilities and R\&D clustering on firm performance: the evidence of Taiwan's semiconductor industry. Technovation, 25(1), 33-43.

Shin, N., Kraemer, K. L., \& Dedrick, J. (2009). R\&D, value chain location and firm performance in the global electronics industry. Industry and Innovation, 16(3), 315-330.

Siegel, J. J., \& Schwartz, J. D. (2006). Long-term returns on the original S\&P 500 companies. Financial Analysts Journal, 62(1), 18-31.

Teirlinck, P. (2017). Configurations of strategic R\&D decisions and financial performance in small-sized and medium-sized firms. Journal of Business Research, 74, 55-65.

Tubbs, M. (2007). The relationship between R\&D and company performance. Research-Technology Management, 50(6), 23-30.

VanderPal, G. A. (2015). Impact of R\&D Expenses and Corporate Financial Performance. Journal of Accounting and Finance, 15(7), 135.

Wang, C.-H. (2011). Clarifying the Effects of R\&D on Performance: evidence from the high technology industries. Asia Pacific Management Review, 16(1), 51-64. 